\title{
Performance of Agriclinics and Agribusiness Centers Scheme in India - A Case of Gujarat
}

\author{
Pragneshkumar K. Patel ${ }^{1}$, Chirag R. Patel ${ }^{1}$, G. B. Chaitra ${ }^{2}$ and Chidanand Patil ${ }^{3 *}$ \\ ${ }^{1}$ Sankalchand Patel University, Visnagar, Gujarat, India \\ ${ }^{2}$ Malwa College, Bathinda, Punjab, India \\ ${ }^{3}$ Department of Applied Agriculture, Central University of Punjab, Bathinda, Punjab, India \\ *Corresponding author
}

\section{A B S T R A C T}

\section{Keywords}

Agriclinics and

Agribusiness

Centre, agricultural

extension,

technology transfer, employment

Article Info

Accepted:

08 January 2020

Available Online:

10 February 2020
The government of India started Agriclinics and Agribusiness Centre scheme in the year 2002 for setting up agri-ventures by agriculture graduates to strengthen the technology transfer, public extension system and employment generation in rural areas. The trained candidates under the scheme are eligible for getting a subsidy of 36 percent in case of General category and 44 percent for women, SC/ST, north eastern and hill states candidates. Credit linked, composite and back ended subsidy with a lock in period of three years is provided under the scheme. The present study is an attempt to study the performance of ACABC scheme in Gujarat. The findings of the study revealed that success rate of the ACABC scheme was high in the states of Maharashtra followed by Uttar Pradesh and Tamil Nadu. The top three activities in which the more agri-ventures were established in Gujarat were Agri-Clinics and Agribusiness Centres, Dairy/Poultry /Piggary/Goatary and Agri-Clinics. Based on the data, on an average 38.87 percent of the trained candidates under the ACABC scheme had established their agri-ventures in Gujarat. National School for Public Leadership, Ahmedabad and Shashwat Sheti Vikas Pratishthan, Amreli Sub Center were holding more than 50 percent share and performed well in training the candidates and more number of agri-ventures had been established by the candidates who had undergone training by these two training institutes.

\section{Introduction}

Agriclinics and Agribusiness Centers $(A C A B C)$ is a subsidy based credit linked scheme for setting up agri-ventures by agriculture graduates launched by the government of India to strengthen the technology transfer, public extension system and employment generation in rural areas and has proved in a healthier way (Bondre et al,
2017). Agriclinics and Agribusiness Centres provide a major opportunity to create gainful self-employment opportunities to unemployed agricultural graduates and support to agricultural development (Kumari et al., 2016).

As the agricultural input agencies will be located in the cities and farmers need services in villages, it is therefore the Agriclinics and 
Agribusiness entrepreneurs who are from the grassroots of the villages will better serve the needy farmers locally and timely, and in doing so, the cost of cultivation will be reduced and income levels will be increased substantially leading to much satisfaction to both farmers and agripreneurs (Shekar et al., 2013). The Global Agrisystems mid-term evaluation of ACABC scheme reported that the major benefit to the farmers availing the services of agriclinicscenters was the increased awareness among farmers on scientific ways of farming (Bondre, 2017).

Presently, 45 days free residential training programme is provided to the candidates under the ACABC scheme. After successful completion of the training programme the trained banks will provide loans up to 20 lakhs for individual projects and up to Rs. 1 crore for group projects. The subsidy component under the ACABC scheme is 36 percent for general category and 44 percent for women, SC/ST, candidates from north eastern and hill states (ACABC database, 2020).

\section{Materials and Methods}

The primary objective of the study is to evaluate the present situation and performance of the Agriclinics and Agribusiness Centres scheme in Gujarat. The present study was based on the secondary data collected from various websites, journals, research studies, etc. For studying the various issues relating to the performance of Agriclinics and Agribusiness Centres scheme a wide range of literature review was also conducted.

The ultimate purpose of the study was to analyse the various aspects, issues and progress of the Agriclinics and Agribusiness Centres scheme on the basis of performance in India and particularly in Gujarat.

\section{Results and Discussion}

Performance of ACABC scheme in India from April 2002 to March 2019 is represented in Table 1. Maharashtra followed by Uttar Pradesh and Tamil Nadu were performing well in terms of the number of candidates who got trained $(24.21 \%, 21.88 \%$ and $10.85 \%$ respectively) and also in terms of establishment of agri-ventures by the trained candidates $(28.29 \%, 24.97 \%$ and $13.01 \%$ respectively). From the table it was clear that a total of 1904 candidates got training under the ACABC scheme and 740 candidates had established their agri-ventures under the scheme from 2002 to 2019. The performance of Gujarat was at eighth position in terms of number of candidates who got training and also in terms of establishment of agri-ventures under ACABC scheme. Except Nagaland (21), the performance of ACABC scheme in terms of establishment of agri-ventures by the trained candidates was poor in case of northeastern states (Meghalaya - 3, Arunachal Pradesh - 3, Mizoram - 0, Sikkim - 1 and Tripura - 1).At all over India basis, a total of 65790 candidates have been trained under the scheme and 28131 agri-ventures have been established by the trained candidates accounting to 42.75 percent as the success rate.

Bairwa et al., (2014) revealed that southern states of India viz., Tamil Nadu, Maharashtra and Karnataka had very good status in terms of women training and agripreneurship in comparison to the north-eastern states of the country recommended that the government should provide special attention on the implementation of Agriclinics and Agribusiness Centres Scheme in the north eastern states of the country. The farmers in the remote areas were not fully aware of ACABC scheme, lack of proper extension network for educating farmers on dairy/poultry/fishery enterprises, lack of own 
funds to start business were the major pressing problems faced by farmers in Assam (Savapandit and Gogoi, 2017).

The progress of ACABC scheme in Gujarat in terms of number of candidates trained and number of agri-ventures established from 2002-03 to 2018-19 is depicted in Table 2. A total of 1904 candidates were trained and 740 agri-ventures were established by the trained candidates under ACABC scheme. Highest number (219) of candidates were trained in the year 2018-19 and highest number of agriventures were established (110) under ACABC scheme in the year 2016-17. Based on the data, on an average 38.87 percent of the candidates had established their ventures.

The motivational factors need to be identified which will going to increase the establishment of more number of agri-ventures by the trained candidates. Parihar and Boyal (2018) revealed that the success rate of $A C A B C$ scheme in India was not satisfactory i.e., only 43 percent success rate was observed. The major constraints faced by the trained agripreneurs in successfully running agriventures under ACABC scheme were competition from the existing dealers, problems in availing bank loans, high rate of interest and inadequate hand holding support from the nodal training institutes (Kumari et al., 2016).

Activity-wise agri-ventures established by the trained candidates under ACABC scheme in Gujarat from April 2002 to March 2019 is represented in Table 3. All over India a total of 32 different activities were undertaken by the trained graduates for establishing different agri-ventures. In case of Gujarat, 26 activities were undertaken by the trained graduates for establishing their agri-ventures. The top three activities in which the entrepreneurial activities were successful were Agri-Clinics and Agribusiness Centres (41.76\%),
Dairy/Poultry/Piggary/Goatary (24.73\%) and Agri-Clinics (13.38\%).

Venkattakumar et al., (2016) had identified 14 critical success factors among successful agripreneurs by using rank-based quotient analysis because over 1500 agricultural graduates had been trained under the ACABC scheme but the success rate of establishment of agribusiness ventures by the trained graduates was only 35 percent. Shekara and Durga (2007) revealed that cropping pattern shifts occurred in Maharashtra and Uttar Pradesh due to the intervention of Agripreneurs who got training under the ACABC scheme and also the yield of sample farmers had gone up due to adoption of better package of practices based on the advice of agripreneurs.

In today's' era technology plays a very important role in encouraging farmers to take up entrepreneurial ventures and agro-based industries (Sharma and Patil, 2018). The trained agricultural graduates under ACABC scheme will be play a crucial role in introducing new technologies in agriculture sector and also providing the agricultural extension services to the farming community in villages. By looking into the success of the agri-ventures in rural areas, unemployed youth in rural areas may also be attracted towards taking their own startups in agricultural sector which will help in providing the employment opportunities in rural areas.

A total 200 institutes across India are providing training programmes to the candidates under ACABC scheme. In Gujarat, a total of nine institutes are providing training to the candidates for establishing agri-ventures under ACABC scheme. The institute-wise number of trained candidates and the agriventures established in Gujarat from April 2002 to March 2009 is represented Table 4. 
Table.1 Performance of ACABC scheme in India from April 2002 to March 2019

\begin{tabular}{|c|c|c|c|c|c|}
\hline \multirow[t]{2}{*}{ S.No. } & \multirow[t]{2}{*}{ Name of the State } & \multicolumn{2}{|c|}{ Candidates Trained } & \multicolumn{2}{|c|}{ Agri-Ventures established } \\
\hline & & Number & Percent of Total & Number & Percent of Total \\
\hline 1 & Maharashtra & 15929 & 24.21 & 7957 & 28.29 \\
\hline 2 & Uttar Pradesh & 14396 & 21.88 & 7023 & 24.97 \\
\hline 3 & Tamil Nadu & 7135 & 10.85 & 3661 & 13.01 \\
\hline 4 & Karnataka & 3979 & 6.05 & 1618 & 5.75 \\
\hline 5 & Bihar & 3955 & 6.01 & 1391 & 4.94 \\
\hline 6 & Rajasthan & 3495 & 5.31 & 1333 & 4.74 \\
\hline 7 & Madhya Pradesh & 3284 & 4.99 & 1297 & 4.61 \\
\hline 8 & Gujarat & 1904 & 2.89 & 740 & 2.63 \\
\hline 9 & Telangana & 1642 & 2.50 & 417 & 1.48 \\
\hline 10 & Jammu and Kashmir & 1491 & 2.27 & 191 & 0.68 \\
\hline 11 & Andhra Pradesh & 1167 & 1.77 & 321 & 1.14 \\
\hline 12 & West Bengal & 1163 & 1.77 & 296 & 1.05 \\
\hline 13 & Chattisgarh & 773 & 1.17 & 335 & 1.19 \\
\hline 14 & Jharkhand & 747 & 1.14 & 186 & 0.66 \\
\hline 15 & Assam & 735 & 1.12 & 227 & 0.81 \\
\hline 16 & Haryana & 696 & 1.06 & 233 & 0.83 \\
\hline 17 & Punjab & 656 & 1.00 & 218 & 0.77 \\
\hline 18 & Orissa & 603 & 0.92 & 114 & 0.41 \\
\hline 19 & Uttaranchal & 470 & 0.71 & 159 & 0.57 \\
\hline 20 & Manipur & 439 & 0.67 & 128 & 0.46 \\
\hline 21 & Himachal Pradesh & 421 & 0.64 & 108 & 0.38 \\
\hline 22 & Kerala & 223 & 0.34 & 51 & 0.18 \\
\hline 23 & Nagaland & 184 & 0.28 & 21 & 0.07 \\
\hline 24 & Pondicherry & 135 & 0.21 & 84 & 0.30 \\
\hline 25 & Meghalaya & 35 & 0.05 & 3 & 0.01 \\
\hline 26 & Arunachal Pradesh & 35 & 0.05 & 3 & 0.01 \\
\hline 27 & Delhi & 34 & 0.05 & 6 & 0.02 \\
\hline 28 & Mizoram & 34 & 0.05 & 0 & 0.00 \\
\hline 29 & Goa & 13 & 0.02 & 7 & 0.02 \\
\hline 30 & Sikkim & 9 & 0.01 & 1 & 0.004 \\
\hline 31 & Tripura & 5 & 0.01 & 1 & 0.004 \\
\hline 32 & Chandigarh & 3 & 0.005 & 1 & 0.004 \\
\hline & Total & 65790 & 100.00 & 28131 & 100.00 \\
\hline
\end{tabular}

Source: MANAGE - ACABC Database 
Int.J.Curr.Microbiol.App.Sci (2020) 9(2): 1541-1549

Table.2 Progress of ACABC scheme in Gujarat

\begin{tabular}{|l|c|c|c|c|}
\hline \multirow{2}{*}{ Year } & \multicolumn{2}{|c|}{ Candidates Trained } & \multicolumn{2}{c|}{ Agri-Ventures established } \\
\cline { 2 - 5 } & Number & Percent of Total & Number & Percent of Total \\
\hline $\mathbf{2 0 0 2 - 0 3}$ & 157 & 8.25 & 28 & 3.78 \\
\hline $\mathbf{2 0 0 3 - 0 4}$ & 71 & 3.73 & 11 & 1.49 \\
\hline $\mathbf{2 0 0 4 - 0 5}$ & 82 & 4.31 & 37 & 5.00 \\
\hline $\mathbf{2 0 0 5 - 0 6}$ & 36 & 1.89 & 43 & 5.81 \\
\hline $\mathbf{2 0 0 6 - 0 7}$ & 0 & 0.00 & 16 & 2.16 \\
\hline $\mathbf{2 0 0 7 - 0 8}$ & 14 & 0.74 & 0 & 0.00 \\
\hline $\mathbf{2 0 0 8 - 0 9}$ & 57 & 2.99 & 12 & 1.62 \\
\hline $\mathbf{2 0 0 9 - 1 0}$ & 143 & 7.51 & 37 & 5.00 \\
\hline $\mathbf{2 0 1 0 - 1 1}$ & 104 & 5.46 & 34 & 4.59 \\
\hline $\mathbf{2 0 1 1 - 1 2}$ & 187 & 9.82 & 53 & 7.16 \\
\hline $\mathbf{2 0 1 2 - 1 3}$ & 178 & 9.35 & 84 & 11.35 \\
\hline $\mathbf{2 0 1 3 - 1 4}$ & 104 & 5.46 & 46 & 6.22 \\
\hline $\mathbf{2 0 1 4 - 1 5}$ & 70 & 3.68 & 64 & 8.65 \\
\hline $\mathbf{2 0 1 5 - 1 6}$ & 154 & 8.09 & 41 & 5.54 \\
\hline $\mathbf{2 0 1 6 - 1 7}$ & 165 & 8.67 & 110 & 14.86 \\
\hline $\mathbf{2 0 1 7 - 1 8}$ & 163 & 8.56 & 57 & 7.70 \\
\hline $\mathbf{2 0 1 8 - 1 9}$ & 219 & 11.50 & 67 & 9.05 \\
\hline Total & $\mathbf{1 9 0 4}$ & $\mathbf{1 0 0 . 0 0}$ & $\mathbf{7 4 0}$ & $\mathbf{1 0 0}$ \\
\hline Source: MANAGE - ACABC Database & & \\
\hline & & & & \\
\hline
\end{tabular}


Table.3 Activity-wise agri-ventures established by the trained candidates under ACABC scheme in Gujarat from April 2002 to March 2019

\begin{tabular}{|c|c|c|c|}
\hline S.No. & Project Description & No. of Ventures Established & $\begin{array}{c}\text { Percent of } \\
\text { Total }\end{array}$ \\
\hline 1 & Agri-Clinics and Agribusiness Centres & 309 & 41.76 \\
\hline 2 & Dairy/Poultry/Piggary/Goatary & 183 & 24.73 \\
\hline 3 & Agri-Clinics & 99 & 13.38 \\
\hline 4 & Farm Machinery Unit & 32 & 4.32 \\
\hline 5 & Seed Processing and Marketing & 21 & 2.84 \\
\hline 6 & Veterinary Clinics & 17 & 2.30 \\
\hline 7 & Nursery & 13 & 1.76 \\
\hline 8 & Direct Marketing & 8 & 1.08 \\
\hline 9 & Crop Production & 8 & 1.08 \\
\hline 10 & Value Addition & 7 & 0.95 \\
\hline 11 & Soil Testing Laboratory & 6 & 0.81 \\
\hline 12 & Vermicomposting / Organic manure & 6 & 0.81 \\
\hline 13 & Bio-fertilizer production and Marketing & 4 & 0.54 \\
\hline 14 & Organic Production/ Food Chain & 4 & 0.54 \\
\hline 15 & Pesticides Production and Marketing & 4 & 0.54 \\
\hline 16 & Vegetable Production and Marketing & 4 & 0.54 \\
\hline 17 & Floriculture & 3 & 0.41 \\
\hline 18 & Animal Feed Unit & 2 & 0.27 \\
\hline 19 & Agriculture Journalism & 2 & 0.27 \\
\hline 20 & Mashroom Cultivation & 2 & 0.27 \\
\hline 21 & Agro-Eco Tourism & 1 & 0.14 \\
\hline 22 & Contract Farming & 1 & 0.14 \\
\hline 23 & Cultivation of Medicinal Plants & 1 & 0.14 \\
\hline 24 & Landscaping + Nursery & 1 & 0.14 \\
\hline 25 & Production and Marketing of Bio-Control Agents & 1 & 0.14 \\
\hline \multirow[t]{2}{*}{26} & Apiary & 1 & 0.14 \\
\hline & Total & 740 & 100.00 \\
\hline
\end{tabular}

Source: MANAGE-ACABC, Database 
Table.4 Institute-wise number of trained candidates and agri-ventures established in Gujarat from April 2002 to March 2019

\begin{tabular}{|c|l|c|c|c|c|}
\hline S.No. & \multicolumn{1}{|c|}{ Name of the Institute } & \multicolumn{2}{|c|}{ Candidates Trained } & \multicolumn{2}{|c|}{$\begin{array}{c}\text { Agri-Ventures } \\
\text { established }\end{array}$} \\
\cline { 2 - 5 } & & Number & $\begin{array}{c}\text { Percent of } \\
\text { Total }\end{array}$ & $\begin{array}{c}\text { Number } \\
\text { Total }\end{array}$ \\
\hline $\mathbf{1}$ & $\begin{array}{l}\text { International School for Public Leadership, } \\
\text { Ahmedabad }\end{array}$ & 566 & 28.88 & 251 & 32.77 \\
\hline $\mathbf{2}$ & $\begin{array}{l}\text { ShashwatSheti Vikas Pratishthan, Amreli Sub } \\
\text { Center }\end{array}$ & 487 & 24.85 & 215 & 28.07 \\
\hline $\mathbf{3}$ & $\begin{array}{l}\text { Indian Society of Agribusiness Professionals } \\
\text { (ISAP), Gujarath }\end{array}$ & 242 & 12.35 & 114 & 14.88 \\
\hline $\mathbf{4}$ & $\begin{array}{l}\text { Vivekananda Research and Training Institute, } \\
\text { Kutch }\end{array}$ & 168 & 8.57 & 64 & 8.36 \\
\hline $\mathbf{5}$ & Jai Research Foundation, Vapi & 153 & 7.81 & 62 & 8.09 \\
\hline $\mathbf{6}$ & $\begin{array}{l}\text { Mitcon Consultancy Services Ltd.(MCSL), } \\
\text { Amreli }\end{array}$ & 102 & 5.20 & 13 & 1.70 \\
\hline $\mathbf{7}$ & Ganpat University, Meshana & 91 & 4.64 & - & - \\
\hline $\mathbf{8}$ & Gujarat Agricultural University, Anand & 80 & 4.08 & 15 & 1.96 \\
\hline $\mathbf{9}$ & $\begin{array}{l}\text { Entrepreneurship Development Institute of } \\
\text { India, Bhat }\end{array}$ & 71 & 3.62 & 32 & 4.18 \\
\hline & & $\mathbf{1 9 6 0}$ & $\mathbf{1 0 0 . 0 0}$ & $\mathbf{7 6 6}$ & $\mathbf{1 0 0 . 0 0}$ \\
\hline
\end{tabular}

Source: MANAGE-ACABC Database

From the table 4 it is clear that International School for Public Leadership, Ahmedabad and Shashwat Sheti Vikas Pratishthan, Amreli Sub Center were holding more than 50 percent share and performed well in training the candidates and more number of agriventures have been established by the candidates who had undergone training by these two training institutes. The performance in terms of number of candidates getting trained was low in case of the institutes such as Entrepreneurship Development Institute of India - Bhat, Gujarat Agricultural University Anand and Ganpat University -Meshana.

Taufiq et al., (2016) highlighted that the major constraints faced by the trained agripreneurs under the agriclinics and agribusiness centres scheme were high rate of interest, lack of subsidy component and lack of collateral security component in the scheme.

In conclusion the Agriclinics and Agribusiness Centers scheme is a good initiative of Government of India which will help in providing agricultural extension services in rural India and also in generating entrepreneurial opportunities for the rural youth. The success rate of the ACABC scheme was high in the states of Maharashtra followed by Uttar Pradesh and Tamil Nadu both in terms of training candidates and also in terms of establishment of agri-venures by the trained candidates. The Gujarat state stood at eighth position both in terms of output of trained candidates under the ACABC scheme and also in terms of establishment of agri- 
ventures by the trained candidates. The top three activities in which the more agriventures were established in Gujarat were Agri-Clinics and Agribusiness Centres (41.76\%), Dairy/Poultry/Piggary/Goatary (24.73\%) and Agri-Clinics (13.38\%). National School for Public Leadership, Ahmedabad and ShashwatSheti Vikas Pratishthan, Amreli Sub Center were holding more than 50 percent share and performed well in training the candidates and more number of agri-ventures have been established by the candidates who had undergone training by these two training institutes. More importance may be given in transforming the trained candidates under ACABC scheme to start their own business which will going to help in turning unemployed youth to entrepreneurs and also in providing the agricultural extension services in rural areas.

\section{References}

Bairwa, S. L., Kushwaha, S., Lakra, K. and Meena, L. M., (2014) Women empowerment through agri-clinics and agri-business centres scheme in India. International Journal of Commerce and Business Management, 7 (1): 181185.

Bondre, S. V., Gupta, N. S. \&Sontakke, S. N., (2017) Agriclinics and Agribusiness Centres Scheme: Attracting and providing opportunities to agripreneurs. Rashtriya, 12 (2): 71-75.

Kumari, M. V., Durga, P. K., Bhanusree, M. R. and Chandrika, M., (2016) Major Constraints faced by the trained agripreneurs in successfully running their agriventures under the scheme of ACABC in Andhra Pradesh. International Journal of Agricultural Science and Research, 6 (3): 241-244.
Parihar, T. B. and Boyal, V. K., (2018) Agricultural Extension Services by Agri-Clinic and Agri Business Centres (ACABCs) Scheme in Rajasthan. International Journal of Advanced Scientific Research and Management, 1: 188-193.

Savapandit, R. and Gogoi, M., (2017) Impact Study on Agricultural Extension Services to Farmers by Agri-Clinic and Agri Business Centres (ACABC Scheme) - A Study in Assam, AgroEconomic Research Centre for NorthEast India.

Sharma, M. and Patil, C., (2018) Recent trends and advancements in agricultural research: An overview. Journal of Pharmacognosy and Phytochemistry, 7 (2): 1906-1910.

Shekar, S. C., Bahal, R. and Lakshmi, K. B., (2014) Effectiveness of Agri Clinics in Promoting Paid Extension Services among Farmers. International J. of Exten. Edu., 10: 27-33.

Shekara, P. C. and Durga, P. K., (2007) Impact of Agriclinics and Agribusiness Centers on the Economic Status of the Farmers. The IUP Journal of Agricultural Economics, 4 (3): 66-78.

Taufiq, A., Shamsul, H. and Rifat, H., (2016)Analyzing the constraints faced by the trained agri-preneurs under agri-clinics and agri-business center scheme. Journal of Community Mobilization and Sustainable Development, 11 (2): 202-205.

Venkattakumar, R., Chandrashekara, P. \&Sontakki, B. S. (2016) Critical Success Factors for Agri-clinics and Agri-business Centres (AC and ABC) Scheme in India. Indian Res. J. Ext. Edu. 16(1): 1-8. 


\section{How to cite this article:}

Pragneshkumar K. Patel, Chirag R. Patel, G. B. Chaitra and Chidanand Patil. 2020. Performance of Agriclinics and Agribusiness Centers Scheme in India - A Case of Gujarat. Int.J.Curr.Microbiol.App.Sci. 9(02): 1541-1549. doi: https://doi.org/10.20546/ijcmas.2020.902.177 